\title{
Saludo a la octava promoción (2014-2015)
}

Alfonso Castrillón Vizcarra

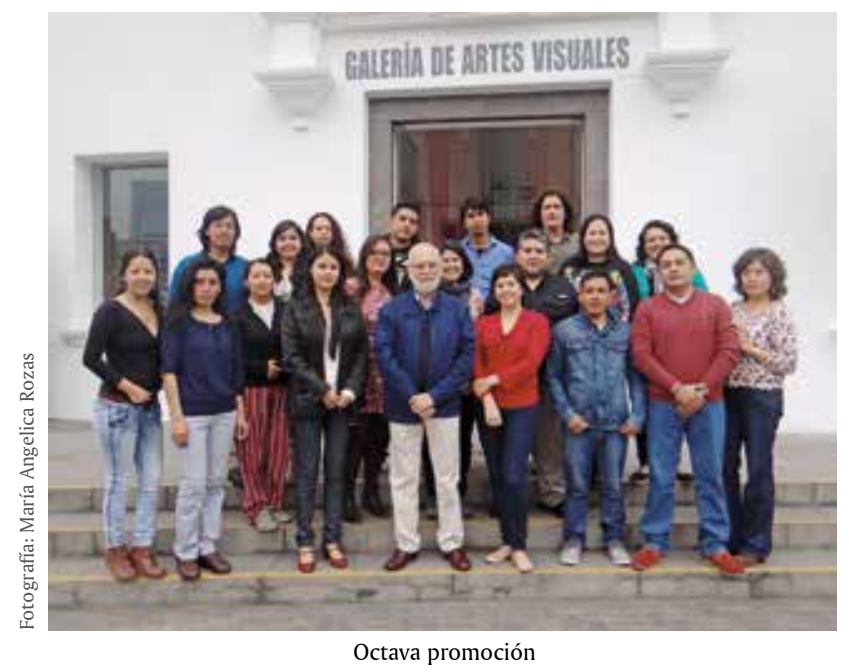

Cada año, cuando me dispongo a redactar esta nota para Illapa, me apresuro a decir que no es un saludo de despedida sino, al contrario, uno de bienvenida. Y es cierto, porque los que egresan de la maestría no van a desaparecer, como quienes se van a un largo y lejano viaje, sino que se integran a una comunidad de profesionales donde van a alternar en muchas oportunidades con sus colegas.

iBienvenida, pues, octava promoción de la Maestría en Museología y Gestión Cultural!

La Maestría se creó con la finalidad de formar profesionales dedicados a la protección del patrimonio, su puesta en valor, y la atención de los públicos, para perpetuar la memoria de nuestras culturas ancestrales y tender un puente con el presente; en suma para fortalecer nuestras raíces, nuestra identidad. La labor del museólogo se está valorando, poco a poco, en su verdadera dimensión, como fundamental para sostener nuestra cultura y difundirla dentro y fuera del país. En este sentido muchos países latinoamericanos nos sacan una ventaja considerable, pero en lugar de decepcionarnos nos da más fuerza para proponer los cambios necesarios y alcanzar un nivel respetable. La juventud los favorece. Aprovechen esa fuerza, la tenacidad de los espíritus luchadores y la razón que da el saber, para cambiar la realidad.

Quisiera terminar citando un párrafo dedicado a los egresados del 2011, pero que igual viene al caso: "Por fin quiero invitarlos a que reflexionen sobre el título que recibirán cuando presenten la tesis. Maestro significa "Persona que enseña una ciencia, arte u oficio o tiene título para hacerlo". Pero maestro no solo en el aula sino en todas partes y con cualquiera que alguna vez en la vida se les acerque en busca de consejo y amistad. Sobre todo con los colegas. Ustedes han estado dos años juntos y, quiéranlo o no, han creado lazos de solidariedad, lealtad y respeto. Existe una ética profesional del museólogo que exige un comportamiento limpio en la carrera, buena disposición para el trabajo en equipo y rechazo de todo irracionalismo, fundamentalismo y racismo, como también de la maledicencia.” Premunidos de estas armas podrán afrontar los retos más difíciles que la vida les vaya poniendo en el camino. 